\title{
Michael S. Harper Interviews Henri Coulette
}

\author{
Introduction
}

HEN R I COULE T T E and I met in 1959 when he was fresh from the Writers' Workshop and I was a transfer student from City College, where LA State had once been housed, and we shared turf, the same section of Los Angeles where we'd both lived. Coulette was instrumental in my going to Iowa a few years later. In '59 I was working as a postal clerk and commuting to a new LA State College campus, in a Mexican neighborhood. Two incidents flare in my mind as comments on Coulette's sense of decorum, one in his office, the other in the classroom. When I sought counsel on my writing, one afternoon before going to work, he quickly turned my questions to our favorite boxer, "Sugar" Ray Robinson, past his prime, but still an icon with unforgettable moves, defense, and punching power with either hand. Coulette avoided too much talk about technique, for I knew little about prosody-his sacred talk-and as a novice in the post office was learning to count on the facing table, dis-remembering the basic training of a good ear, a sense of the line, the cadences of talk, the few great moments of history and sport. Coulette deliberately pulled his punches re my deficiencies while he pointed out poor diction, loose structure, wasted tropes; he looked for an image, a metaphor of instruction instead. Another time, in a creative writing class of commuters, all semi-literate, some of us too arrogant to be scared, Coulette-always dapperly dressed_came in to teach. $\mathrm{He}$ asked for any new work for our class discussion, waiting through our long silence; then he asked the same question, without meanace, once more, paused an extra moment, then picked up his books and departed. Sitting there in a daze, in mid-semester, we were veterans expecting the word, which meant we expected to be entertained. Coulette didn't return to class that day, and on the short drive to the facing table for the sorting of mail, the image of Sugar Ray came back to me. Later, Coulette invited John Berryman, Thom Gunn, and Philip Levine to campus for readings; Berryman read his early dream songs, Gunn from On the Road, Levine from On the Edge; all were works-in-progress, and Coulette even appeared, as a persona, in "The Negatives," one of Levine's poems. Coulette was teaching by example, his own poems alternative strategies in prosody and tradition, for he read deeply in literature and 
popular culture, and he loved mysteries, sport, and the movies. His wit disguised surfaces and levels of discourse that acted as decoys to "responsibilities" later understood when one was alone on the blank page, and his hints resonated in that privacy. Then, he was a "man without a book," and when his The War of the Secret Agents and Other Poems won the Lamont Poetry Prize in 1965 some of his students felt justified in learning to wait. In 1971 The Family Goldschmitt appeared, and Coulette, the methodical worker of tightly made poems, showed through the gloss of double agent, looking backwards and forwards at facts and longings, "The Blue-Eyed Precinct Worker" back in his district. Our interview was begun at Yaddo, in Saratoga Springs, New York; it was the height of the racing season. In that magic circle I asked Henri Coulette about "the Golden Age" of the Workshop.

Michael S. Harper Brown University

The Extras

Today, they are the subjects of a king, And they must cheer his passage through the town This coronation morning, cheer his taking Purple and ermine, the sceptre and the crown.

They have, they will again, take after take, But now the star, his agent at his sleeve, Has disappeared. Their thoughts come back to them, Like shadows, and they rest from make-believe.

Duchess and chimney sweep are Blossom and Hank.

A light is asked for, and a light is given.

Gossip is music played upon the breath

By wicked tongues, and anecdote is heaven.

Simply human is what their costumes smell of;

Simply human is what their faces say.

They make the lobby and the street look real.

Practicing everyday for Judgment Day, 
They draw the circle that becomes a crown;

They draw bathwater on a bended knee,

And curtains on the night, and they draw blood.

They are the after that comes After Me.

MSH: This poem you've just finished, where does it come from?

HC: The extras are movie extras. After Santa Fe and before the army, I worked in a number of jobs beginning with being a messenger boy. I saw the extras sitting outside the sound stages gossiping or reading the Daily Racing Form, waiting for the next take. Their job was to give the world a face, to make the lobby and the street look real.

MSH: Were you drafted?

HC: I volunteered. I would have been drafted; so I thought why waste time? Then I was crazy enough that I volunteered for jump school. Fortunately they closed down the jump school before I got there.

MSH: How old were you then?

HC: Seventeen.

MSH: And you didn't go to high school at all?

HC: No. I started off, I was going to go to Santa Fe High, but I didn't. Things had gotten kind of mixed up.

MSH: You were doing some reading, weren't you?

HC: Yes. I was always a reader. My love of literature started when I was a boy of about nine or ten and I used every month to go down and get Air Trails magazine; they had Bill Barnes novelettes in them. I don't know whether I loved them because George Eaton, which was actually a stable of guys, was writing those things, or because they were so beautifully illustrated. Then one of my brothers had a girlfriend named Harriet Ross who gave me thirteen volumes of the motor boys. I pay my dues to them, you know, "The War of the Secret Agents." I loved those things.

When I was fourteen, I went to the Santa Fe Public Library and somebody told me I should read the Three Musketeers. The librarian made a mistake and gave me Tiffany Thayer's Three Musketeers. That was a popular, updated version written in the 1930's and about as racy a book as you could get in 1942. I remember on about the second page a woman who ends up being Milady de Winter goes to confession to a young priest. She tells him her thoughts, her dirty thoughts, and it says they promptly sank to the floor of the confessional and galloped at a great rate without moving more than a few inches. I thought, oh my god, there are actually books about what I've been thinking. 
MSH: Who got you going on poetry?

HC: Tom McGrath. He was teaching at LA State. I'd been reading poetry all along, and then I tried writing a poem and I showed it to Tom. He said, "That's good, let me see some more." Hell, I didn't have anymore. So I started writing more. He was a terribly important influence. A lot of other people were encouraged by him. He was a good teacher. MSH: What was he having you read at the time?

HC: Yeats, on the one hand, and Neruda, in the Angel Flores translation, on the other. One of the good things about him was that he believed in both the raw and the cooked. He didn't exclude one or the other. He felt that somehow or other the big trick would be to bring the two together, if one could.

MSH: What about his politics?

HC: That finally got him fired from LA State because he got caught up in one of the witch hunts. I pulled off a coup that delayed it for one year. They weren't ready to announce that they were going to fire him. But they didn't want him to be the advisor to the literary magazine in case they were able to fire him. You know, they wanted him to have the lowest possible profile. So I got a letter, a telegram one night, from one of the deans, listing all the people in the English Department who were acceptable as faculty advisors. They named everybody except McGrath. I was the editor, and one of my staff members was also on the college newspaper staff. So I had her plant a story the next day to the effect that we had chosen McGrath a week before. We told McGrath, and he agreed it was all right for us to do this.

It was an attempt to flush them out, to make them come out and say, "Okay, we don't want him." To do that in public. As a result they decided to bite the bullet, and it took them another year before they finally got rid of him.

MSH: Later you came back to your Alma Mater to teach?

HC: Yeah, after six years or so I came back to his job.

MSH: In the meantime you'd been to the Iowa Workshop. This is a good time to talk about Engle as an influence. One of the things I'd like to hit on is his marksmanship, the way in which he could pick and choose talent. I know he always had high regard for you. I thought that you two had a kind of rapport.

HC: The thing that I liked about him was. ... He was the son of a horse trader. And I figured that's what he was too, except that instead of horses he was trading poets. Either you went off to the races or you went off 
to the glue factory. He was a man who had a fantastic gift for raising money and distributing it to writers. I know that a lot of poets, a lot of people who went through Iowa City didn't like him. But I always did, and I could josh him. I called him "Massa Paul." Somehow or other that was fine. That was the basis of our getting along. Actually I got away with murder, because I never produced as much, as rapidly, as he liked his poets to. He really wanted them to be out there running everything, winning the stakes, cups and trophies.

As near as I can tell, he really invented this whole poetry workshop racket. Everybody has his own factory now; everybody's getting MFA's and he should get credit for it. He was an entrepreneur, a con man, a master of revels; I mean he got the show on the road.

$\mathrm{He}$ gave Robert Lowell a job, when Lowell, because of being a conscientious objector, wasn't getting offers. I always figured he had a real eye for what was good, not just trendy, which a lot of people have. All you have to do is read the right newspaper or journal to learn that. But he had a nose for what was good. And he wanted it in his stable, working for him, so he could say, at The University of Iowa, we've had the following people in the last three years....

MSH: Turning from a "father figure" to your father... The 6th part of "Bitter Suite," is of your father, isn't it?

He plays no more

Whose play was need,

The darkened score,

The broken reed.

That's like a cryptogram for an enlargement, could you amplify?

HC: There's one other poem for him, called "The Invisible Father," in my second book. He was a man in my household. He was always portrayed as the monster. And the crazy thing is that he may have been. He was fifty when I was born. And he may have been a monster before that. I don't know. What my mother did was to turn all three of her sons against my father. She succeeded very well with the middle brother. I don't know about my older brother. I didn't know him, he was nineteen years older than I, but my middle brother had a quarrel with him at the age of seventeen or eighteen and changed his name to my mother's maiden name, O'Reilly. I mean that's really joining my mother's camp. But to me my father was a very gentle man. He was 
a musician, and when there' $\mathrm{d}$ be a conflict in the house, as there often would be between him and my mother, he'd disappear into his study and practice; he'd practice hours and hours and hours.

He played the clarinet. He was professional on eight instruments, but that was the one where he could really make money. He died suddenly in 1945 of a heart attack, died in my arms. It was a week before my eighteenth birthday, and I was in uniform, on leave. At his funeral he got one of the finest epitaphs you could get. One of his old colleagues, a musician named Storch, came up to me and said, "Your father had perfect tone." I'd like to be good enough for that.

MSH: Would you read "The Invisible Father?"

HC:

The Invisible Father

You might have worn bandages,

Sir, like in the old story.

After all, you were a wound,

Or at best, the breath of Absence.

One of us said, once, that you stood

On the dark side of mother.

I think now that you stood

Behind us, like the sun,

Fathering our shadows toward her.

You have become the music

You practiced hours and hours

Elsewhere in that strange house,

The difficult passage I hear

Suddenly in context.

MSH: Beautiful poem. And you were back on leave. "Life with Mother" hits the other side of your inheritance; tell me something about it. Did your mother see it? Did she like it? 
HC: She saw it and it was one of the most troublesome moments... . I postponed, for a long time, letting her have the book. She kept after me for months, saying you always forget to bring me a copy; and I decided it was probably safe, that she'd never read it. My god, she sat down and read it from cover to cover and then she asked me about that poem. What she wanted to know was whether I loved her or not and whether that was a cruel poem. The thing is, it is a cruel poem; at the same time I loved her. Her whole involvement with the I Am business and her sort of madness is in that poem, and also a phrase that I remember growing up with that was in my household when I was a boy. If you told something that wasn't the truth, they would ask, "Were there any ashes on the sidewalk?" Nobody seems to know this expression. So I was pleased to be able to get that into the poem.

\section{Life with Mother}

Everything's left to the imagination, Mother says, and winks an eye, green and beautiful.

I nod encouragement, and wink back, imagining myself anywhere but here, in this room, with this woman.

She has been very famous in her lifetimesQueen Elizabeth, Alexander Hamiltonthis poor Irish daughter of the man who invented the Nabisco fig newton, this woman who has no friends.

She is being watched by agents of the Kremlin; an agent herself of the Ascended Masters, she knows, she knows. St. Germain is here, now, in this room. See, the light bulb is blinking! $\mathrm{K}-17$ is here too,

and the Lord Kathumi is in the kitchen. I nod, I must nod, 
or be a Black Magician.

And if I did speak, what could I say?

There are ashes on all your sidewalks, Mother.

There are ashes in my mouth.

MSH: You have a poem in The Family Goldschmitt "On mange l'orange et jette l'ecorce?"

HC: "One eats the orange and throws away the peel." It was something Henri Déricourt, the prototype for the double agent Hilaire Pentecôte in "The War of the Secret Agents," said in a letter to Jean Overton Fuller. He was doing some sort of commercial flying in Vietnam during the sixties, and he told her, if he were to be killed, not to investigate the circumstances of his death. A short time later, she got word that he had been killed in a plane crash. I forget sometimes that I have written about real people.

MSH: Let's talk about "The War of the Secret Agents." I think it's a marvelous conception and you've got enough distance on it now so that you can probably talk about it. A note in the back says it is based on Fuller's remarkable Double Webs.

HC: Yes.

MSH: But it's based on something else, also. I mean that might have been a catalyst.

HC: Well, what I discovered, and this is not the reply you thought you were going to get. But I discovered some years later, after years of analysis, that "The War of the Secret Agents" was really a way I had of describing my neurosis. That was one of the functions of the poem, to describe the way I saw the world. I know that's what it is about. It is part of my whole response to life, that I didn't go to high school. When I was fourteen I went to work. I went to work and I was a terribly frightened little kid. I was suddenly thrown into an adult world, had to figure out what that game was. What did they expect of me? How was I to survive in that world? And I found out one of the ways that you survive is to keep your mouth shut. You become a secret agent. You don't let people know what you're thinking or feeling, because if you do, they'll fire you. That's the worst thing that can happen to you, to be fired.

I was fired once because I told the truth. The guy said to me why weren't you-this was at the Santa Fe Book and Stationery Store-his name was Ned Hale, he was the boss, the manager. He said why weren't 
you here yesterday? And I said because I was sick. He said why didn't you phone? I said I don't have a telephone. He said everybody has a telephone. You're fired.

I didn't have a telephone. We lived on forty dollars a month from my father, that he sent, and my forty dollars a month. Eighty dollars a month. My mother and I lived on that. So, I learned. I mean that moment I learned, by god, you're a secret agent. If they want you to lie, you tell them a lie. "There was a terrible traffic accident and I was so busy carrying the bodies away that I couldn't come to work." That was part of it.

Also, I was talking to Byron Burford about Hollywood, and how people never took that seriously enough. It's the great fix of our time. I wanted to write something that would be like a boy's book, like a spy movie, that would be a thriller, an entertainment by Graham Greene. I wanted to make it as real and vital as television, as soap opera, except in good language. I don't want poetry out in left field belonging only to people with marvelous sensibilities.

MSH: What about the cast of characters?

HC: Well, Jane Alabaster-my former wife went to school with a girl by that name. I thought it a marvelous name; if you're going to have a last name, why not Alabaster? And she ends up being a spinster. Of course, she's based on this English woman, Jean Overton Fuller, I mean to the extent that Fuller portrays herself in her own book. I also remembered Jane Cooper, a spinster and a Jane, who had a certain lovely quality. And there are parts of myself in the poem. One of the things that I learned about myself is that I am a lot like Prosper, the chief agent. I keep trying to take care of people. There are people that I'm worried about, concerned about, you know. I grew up with a mother who needed, or told people that she needed to be taken care of. That's my sort of great responsibility. I worry about people. Maybe in a neurotic way, but it's my way of operating.

MSH: How about the Germans? Kieffer, the head of the Paris Gestapo? HC: Kieffer is a sort of mirror image of Prosper. They both want to take care of people. They're men caught up in a terribly corrupt and horrifying world, and they want to do the best they can for people. They know that they're going to fail, but they want to try. You know, I'm saying things I've never even thought of before.

MSH: Does that have anything to do with your experience in the army? HC: I wasn't in the army long enough to really.... Well.... I had a 
Captain Lee, a good Captain. One day he came by on inspection. He looked over all my stuff, looked over my rifle and all of that, and snapped it back to me, you know, like that. You catch it and you don't drop it when they do that. And he said, "Coulette, you're a good soldier." I was pleased, because I wanted to be a good soldier. You know, some people would never understand that and a lot of history has gone down the tubes since then. But back then, I wanted to be a good one.

MSH: Tell me about T.S. Eliot, the editor.

HC: I thought that was funny, to take the high priest and describe him simply as an editor and sneak him into the poem that way; because when I was growing up, he was, he was God, you know, and everybody went around making the sign of the cross.

Another of the big influences was that I had just read Laurence Durrell's The Alexandrian Quartet, and I had a love affair with it. You know, I reread it years later, and I said shit.

MSH: What can you tell me about the epilogue, "Author to Reader"? HC: This is the only time that I can ever say that I was genuinely inspired. For two and a half years I had been writing "The War" off and on, but writing it to the exclusion of anything else. It's in a six line syllabic stanza that has its own small history. Dee Snodgrass wrote an essay in 1959 in Partisan Review, which he subsequently collected in his book. I think it was called "Finding a Poem."

MSH: I've read it.

HC: Okay. He said certain things about writing in syllabics, that it was a way of being able to drop down to the level of prose and being able to rise up to something else, something higher; at least that's the way it struck him. Well, that was the thing that led me to using syllabics in "The War of the Secret Agents."

Anyway, there was a Friday and a Saturday in which I'd come to the last section. It was the confrontation between Jane Alabaster and Hilaire Pentecôte, the double agent. That was supposed to be it, and I worked and worked and worked and later on that Saturday I finished it. I should have been happy, but instead I felt so sad that it was over, because it was almost like a marriage.

I mean it was something that was there, you could come back to it, you didn't have to say, "Am I going to walk out of the door and meet somebody today? Do I have to start a new poem?" No, you just had to get on with the job. So I got up on the Sunday morning and was walking; I was walking across the living room of the apartment, and all of a 
sudden I said to myself, Hell, I can have an epilogue, and I wrote those twenty-four lines in eleven minutes and never had to revise them. I thought I miscounted in one line, but I hadn't. Two and a half years permitted me to have that moment in which I made as much of a statement as ever I've been able to make about what is important to me. And what that is, quite simply, is people. I write poems about people. That's what makes life worth living, that there are people, and it breaks your heart when they finally get to you.

XVII. Epilogue: Author to Reader

Reader, we are getting ready to pull out.

Archambault has packed the tramsmitter in an old suitcase. Denise is combing her hair.

We are meeting Phono and Cinema downtown in a second-rate bistro.

Prosper has been worrying about Phono;

he has a bad cough.

-And Cinema, I worry

about Cinema, who must insist

on a trenchcoat, of all things. But life goes on,

even here, in its own way.

Reader, you have been as patient as an agent

waiting at midnight

outside a deserted house

in a cold rain. You will ask yourself,

What does it all mean? What purpose does it serve, my being here in this rain?

Reader (you will be known henceforth by that name),

there is no meaning

or purpose; only the codes.

So think of us, of Prosper, silly

Prosper, of Archambault of the marvelous eyes, of Denise combing her hair. 
MSH: I think you were making a statement with the organization of The Family Goldschmitt, particularly when it appeared in 1971. Enormous changes had occurred. Yet, you're sticking to your guns in a quiet way. Your willingness to talk about the assault on the American sensibility, on the language.... Did you sit down and arrange this book with that in mind?

HC: Well, I wanted to write a prose commentary, the way Dante does in La Vita Nuova, so that all the poems would be imbedded in that commentary. But I don't write prose well enough to manage that sort of thing. Anyway, I was trying to talk about what it was like going through those years. Now I have the feeling that those years were among the worst in American history. The Vietnam war was terrible, you know, those wars and riots were terrible. And when we thought we were scoring victories, we weren't. We really weren't, I don't think. Or not so many.

One of the things that, in "The War of the Secret Agents," I felt I was unable to deal with was what had happened to the Jews. It was always in the back of my mind, but Kieffer was a sympathetic figure. In history as well as in my poems. So how do those things happen?

The Family Goldschmitt, as a book, is an attempt to deal with that question, how do those things happen? The Holocaust, how does that happen? That's really where it starts. Bill Fick said in conversation one day that when we were naming the beasts, that was paradise; when we started counting them, it was the modern world. So I swiped that for an epigraph. I went around, and asked Norman Fruman about Jewish names so that I could give the right first names to the family. Ah, and have them say things that were ... well, Grace Schulman saw that what I wanted to do was to write a book, and not just individual poems. But I didn't live up to it. That's why I don't like the book as much as. ... MSH: The 1968 section of the book has an epigraph attributed to Felix Goldschmitt: "Europe had taught him that he was American. And now America would teach him what that meant."

HC: I think you know what that means. I went to Europe in 1967 looking for my roots, and what I was told was that you are an American tourist, and I was. I came back here and looked around and said, well, this is my country. Then I saw the fucking country go crazy. My "Liberal Blue-Eyed Precinct Worker" was no longer liberal in that blind, boylike way. He was my political poet of the sixties, as someone said to me once, discovering how few people were being helped and how 
we were playing games and roles. That's what I felt. I felt an awful lot of us were parading around, looking like heroes. Some guys were getting a hell of a lot of mileage out of the war; some nearly went to pieces, I think, when it was over. I have a feeling ... I don't know, Mike, I don't know whether we all got caught up in learning how to respond to having careers, or something of that sort. It's at that point that I started developing a terrible distrust of the whole world of the poets.

I think that our job is to write poems. And it's a terrible temptation, if you can read them well, to want to go out and read them because that is a very interesting performance, and can be a moving thing. But that is not the essential job. I think that we all got too caught up in dealing with that business, of being performers and having careers. We should have been better to each other.

MSH: In Goldschmitt you have a sequence called "Private Lives." Do you remember when the original conception came to you?

HC: It was when Reagan was governor. It was a poem about Reagan, and I think the one good section still, the one successful part, was "Night Watch." If I were to reprint this, I would reprint only that, and let the rest go.

MSH: Who is "she" in the poem?

HC: Oh, that's Nancy Reagan. Reagan was Governor. I sent the poem to Marvin Bell when I wrote it, and he wrote back and thought that it was too much of a local problem. He was editor of The Iowa Review, and I would like to say, now (laughter), that it is America's problem.

\section{Night Watch}

Cradling her breasts in her hands, She watches him while he sleeps.

A faint blue light touches his lids, Like eye make-up, almost.

Beneath the lids, his eyes move

As the shadows of fish move

In clear water, zigzag.

$\mathrm{He}$ enters the fifth stage.

She feels something touching her, A coldness crystalizing 
In her pores, shimmering there-

The moon on the small of her back.

His mouth opens, his teeth gleam.

She leans closer, catching the word,

Groaning as ice groans, breaking,

And the word is NO, NO, NO.

MSH: There, we've got it in The Iowa Review after all.

Over the last twenty years what would you think are some of the highwater marks in poetry? Berryman's Dream Songs?

HC: The Dream Songs would certainly be one, although they don't wear all that well. One of the things that does succeed is that he actually managed to get his own cranky voice. He had, when he was sober enough that you could understand what he was saying, he just had a marvelous way of talking. And so, he was writing poems that were in a sense exploiting the possibilities of that.

MSH: Berryman was your teacher, and so was Lowell. Maybe you can speak about Lowell, first as a poet, and then both of them as teachers and what they taught you.

HC: All of that took place at Iowa. When I first went there, Karl Shapiro was my teacher for most of the semester. But the strain of commuting from Chicago where he was doing Poetry was too much, so he gave it up, abruptly, and Wallace Fowlie filled out the semester. The next semester Lowell came along and took over. Lowell was, for me anyway, not a very good teacher. I mean I just don't think that he had much of a gift for it. He could misinterpret poems like crazy. That was a shock to all of us, because we had all been trained as part of the New Criticism to be wonderfully skillful at interpreting poems. There were moments that would be so awkward and embarrassing that you'd think he was putting you on. Maybe once in a while he was, I don't know. That Housman poem about the cherry hung with snow, Lowell was talking about it one time in class, about its being about suicide. Everybody just said, what!

The thing he was really interested in at the time, and it was the one thing he could communicate, was texture, what made a line sound interesting, and of course he was making his line sound interesting by all those violent run overs and moving the caesura close to the end of the line, getting in a lot of violence. I think Bly one time said something 
about a kind of unmotivated violence in Lowell's poetry. And it's true. It turns up metrically. Maybe the violence is really a kind of subterranean element in his personality that would creep into almost anything he did. He was good when he talked about texture and about how to improve it. One was thrilled in having Lowell as a teacher, because the two big names then were Lowell and Wilbur. And we had one of them. It was like playing football for Knute Rockne.

MSH: How about Wilbur? Has Wilbur been an influence on you? HC: Oh, I'm sure he has.... This is an interesting point about Lowell and Wilbur, I just thought of it, but I think it's true. Lowell, when he was at his best in his poems, was really interested in the lines; and Wilbur, I think, has always been interested in the stanza, in something that spills over. It's amazing how many run-on lines he has and how many stanzas are not complete in themselves, that spill over onto the next one. You know that fountain poem, "A Baroque Wall Fountain in the Villa Sciarra"? There was a delightful almost childish pleasure that Wilbur would take, just in words, you know, in the sounds of them.

I think also that Wilbur has been important to my time in that he has been a balance. All of us learned how to write the official, sorrowful poem rather early. That was one of the ways we became competent; we really looked at life and found it wanting and voiced our disappointment. We never seemed to write about those elements in life that made it worth living. Wilbur, thank god, was around saying-at least in some of his poems-that the world is also marvelous. He can write about that. MSH: What provoked me a while ago was that you were talking about books that had made a difference over the last twenty years. Obviously, Berryman's 77 Dream Songs. What of Lowell's would you cite? Lord Weary's Castle? Life Studies? For the Union Dead?

HC: Lord Weary's Castle and For the Union Dead. Actually the two best poems that I think he ever wrote, and this is just personal, and may be a very quirky opinion, one of his Imitations, a Rilke poem, about Orpheus, Hermes, and Eurydice. It is, I think, a marvelous Lowell poem. I can't read German, so I don't know what Rilke's like. But I've read enough Rilke in translation to know that Lowell can't imitate Rilke. It's just a way of writing a Lowell poem. It's like the difference between novels and movies when Lowell imitates somebody. Because I think Frost is right. Some poets lend themselves to translation, if they are fortunate in having a translator, as when Zbigniew Herbert had Milosz and Peter Dale Scott. 
Herbert's poems which are not in formal patterns can be translated strikingly. They're heavy on images and lend themselves to a certain kind of thing. And that, of course, comes across. Just like Neruda reads well in translation.

For the last decade and a half, I suppose, people have translated that kind of poetry, poetry with an image in it. We have come to think that's what translation is, or that's what the good poems are in other languages. But that's a half truth. I mean it's great that we can get those poems. It has influenced our poetry, but it's also had a bad effect, because a lot of poems are being written now in which American poets, when they're writing their own poems, sound like a translation from another language. I think that's unfortunate. For me what gets left out is that magic from a word, like "tobacco." It's a marvelous word. And Herbert's formal poems have not been translated. We don't have a complete picture of him at all; we think that he is somebody who is wholly acceptable to Robert Bly and Charles Simic, but he's got this other side to him.

But back to Lowell, the other poem of his that I was going to mention is the first version of "Beyond the Alps." You know that? It's got marvelous things in it, and I think it came at a time when he was not going to be able to write that strictly anymore. I think it had become too much of a strait jacket for him. But in "Beyond the Alps," I think he was dealing with the Catholic experience. One of the nuttiest things he ever did was to become a convert. As soon as you become a Catholic convert, you are automatically one of the craziest, and least interesting people in the world. I don't know if you know about Catholic converts, but all they want to do is tell you about their religion. And if you happen to be born a Catholic-as I was-there's nothing worse than someone coming around and telling you all about Aquinas. Not that you have ever read Aquinas, and it's true that they have, but you know that you don't want to talk about that.

MSH: Hey, you're looking at an altar boy.

HC: Oh, yeah, I forgot. Anyway, he was dealing with all of that experience; then there's the most beautiful passage in all of Lowell in one stanza. It's the voice of Ovid, and he says, "I lie/with the boy crazy daughter of the God,/il Duce Augusto. I shall never die." God, doesn't that sound wonderfully Roman and imperial? Those are the two Lowell poems that I ... it got to the point for me in the later years, that I stopped reading him. I mean there are hunks of Lowell that I have not read, but I know that I will sometime. 
MSH: Let me ask you about a couple of other books which I think are fairly influential. I just want your response on them. Roethke's The Far Field. Was that important to you?

HC: Yes, except I never think of Roethke in terms of books, after the first book, Open House. All his poetry after that runs together, like a collected poems. I think it has something to do with his method, you know the way David Wagoner has been able to take the Roethke notebooks, and in a sense, make Roethke poems out of putting those fragments together; and evidently that is what Roethke did. He wrote lines. He could do this because his philosophical system is monism, $a=a$, and everything in the world is a. All the parts can be interchangeable. It doesn't make a difference, really, where they occur. I'm not putting him down when I say that.

MSH: No, I understand.

HC: There are lines in some of these recent poems that I've been writing, that I like because I feel they are second cousins to certain things that I like in Roethke. They're different, but they're related in a way. For instance, in that one about the extras, there's a line, "a light is asked for and a light is given." Now, of course, I was simply talking on the basic level: somebody wants a light for his cigarette, or his cigar; he asks for a light, and somebody gives him a light. But it also sounds almost like, you know, it has a sort of ring to it. In the beginning was the word. A light was asked for and a light was given. Roethke was able to write poems, about birds, and stones, and all of that jazz, and make it sound, like "This is it!" This is the beginning of the world. This is creation.

I have a tiny anecdote that I'd like to pass along so that it doesn't get lost. I was with Edgar Bowers and J.V. Cunningham one night in Santa Barbara, and Cunningham said to Edgar, well, "Here's a book that you might want to read," and he gave him that biography of Roethke, The Glass House. I said to Cunningham, "I'm surprised that you like Roethke since his best is often in lines and passages." "Yes," he said, "but you take good writing any way you can get it."

MSH: I remember that Cunningham's poems and essays were very influential on you.

HC: Cunningham has been a dominant figure in my thinking. In terms of my teaching career, I owe him a lot, because he has truly a first-rate mind. A marvelous mind. My whole notion of what literature is about derives from him, that a poem is in a sense a statement, that the problem 
of reading somebody's poetry is a simplified version of the basic human problem of trying to understand another without imposing your personality or beliefs upon another. But to really hear them and to really understand them. Now that's the human problem.

MSH: With that in mind, I've got another question about your contemporaries, because your contemporaries are important to me. Let's go back and talk about the people who were at Iowa when you were there, and in the process, let's talk about schooling for a poet.

HC: Let me say one thing right off before I forget it. One thing I'd like to say is that there is such a thing as creative writing. Writing can be taught. Damn well it can be taught. Somebody can learn to write. Now, how well they write will be limited by how much talent they have. But, you can teach it like you can teach somebody to swim or play football or speak a foreign language or sing. I mean you may not be a good singer, but you can learn to sing, you know. So that can be done. And these places are legitimate. They are legitimate to the degree that they are honest about what the odds are so that people don't get fooled simply because they've been permitted to go to school. That's important.

I think one of the best things that ever happened to me was that I went to Iowa and went there, I like to think it, at the golden time.

I mentioned Lowell. When Lowell had a class he permitted thirty students in his class, and it just seemed to us, the snobs in the class, too large and not very manageable, especially for somebody who tended to be vague, and obscure, as a teacher. But Lowell was a nice guy. He was permissive. He was sort of a good daddy, you know, a thirty-six-year-old daddy. Well, when Berryman came into town, Berryman was thirtynine at the time, and he was a real teacher. He was also a showman. When he taught, he had carefully prepared himself for class. I've never prepared myself that way, because the students would kill me. I would tell them everything I've been studying for three days and in fifteen minutes would say class dismissed. But Berryman was able to give you all the information and put on a performance at the same time. One of the great things that Berryman did was to convince you that you were doing one of the few things in life worth doing. He made you feel that you were important. You may not be good at what you were doing but you were doing something worth doing. So there was that. But he reduced the class, the workshop, from thirty to thirteen.

I once wrote down, can't remember them all now, but I once wrote down all the thirteen names, with Levine's help. It was amazing. With 
the exception of one person, Shirley Eliason, who was a sculptor and painter, and whose real interest ultimately was in that direction, everybody else in there went on to write books, and win awards and all. Some of those people were Don Justice, Dee Snodgrass, Jane Cooper, Don Petersen, Phil Levine, Melvin Walker La Folette, Paul Petrie, Frederick Bock, William Dickey, and Robert Dana.

That was the spring of 1954 . Anyway, Berryman reduced it to that small group. For the first class, Berryman took a poem by a woman who was married to a doctor who worked at the University hospital. It was a poem, if I remember it accurately, that was mainly obscure but to the extent that he could understand it, it seemed to be an attack upon doctors. Maybe she was unhappy about her husband, I don't know. But Berryman devoted the entire period to destroying that poem, and defending the medical profession, and citing all sorts of obscure books and everything of that sort, and at the end of the hour he said to the thirty assembled people, for next Monday, you all have a Petrarchan sonnet for me. And at the next Monday's meeting there were thirteen Petrarchan sonnets; that's where we went from thirty to thirteen. Justice came in with that one about the Garden of Eden, which is in The Summer Anniversaries, which now, happily, in his Selected Poems, has the dedication for Berryman.

MSH: What are some other influential books over the last twenty years? HC: Well, the twenty years begin really with something like Heart's Needle. It came out in 1959 and won The Pulitzer Prize the next year. I haven't read that book for a long time. But I think if I did, I would find that it stands up well, especially the title poem.

MSH: "The world moves like a diseased heart packed with ice and snow."

HC: People forget the history... but at that time it was absolutely astonishing. Here's a guy writing about his wife in Iowa City, about his kid, about living next door to the city jail, and stuff of that sort, and god it was a breath of fresh air. It was marvelous. But it also opened the door to an enormous amoung of garbage. I remember when people in the fifties were saying that everybody was an academic poet and that it was dull as dishwater. There's a lot of truth to that, but you can say exactly the same thing now except you'd say free verse instead of meter.

MSH: Why don't you talk about the conception of Heart's Needle because you were probably there when he was writing that. There are wonderful poems in it, favorites that I have. One is "The Marsh" which 
begins with all that excitement, "Swampstrife and spatterdock." There's the great "Papageno" poem, and the two songs, both about love and sex. And there's a poem that doesn't get nearly as much attention as it deserves, "Orpheus." Then, of course, "Heart's Needle"; there are tremendous moments in there which move me greatly because of the combination of a clearly felt circumstance cleanly delivered and its level of artifice. I'm talking about the competence of its versification, meter, rhyme. You are disarmed from seeing the controlling mechanics in that book. Maybe since you were there....

HC: You've stirred up a lot of things for me. Let me see if I can catch some of them. I've wanted to say that one of the things that I've known for a long time, a true piece of history, is that Dee was working on the first versions of the "Heart's Needle" cycle when he was studying under Lowell. And of course that's where Lowell got it. I resented the fact that when Lowell was interviewed for the Paris Review, he said something like, some people will say he influenced me and some people will say I influenced him, and I don't know. He knew damn well. But something else that happened never occurred to me until this moment. Berryman came after Lowell. Now Dee was going through a bad phase. I think his life wasn't working well when Berryman was there. But Berryman had seen, I'm sure that Berryman would have seen, those same poems by Snodgrass. It could then be that Snodgrass is responsible for that confessional element in the Dream Songs that Berryman always lied about, saying that Henry has nothing to do with him, which was always such a joke. Although it still may not have hit Berryman until Lowell had picked it up. That's possible.

MSH: How about your other classmates? You and Phil Levine have been close over a good part of your adult lives. Tell me something about his development, and tell me something about the relationship between the two of you. The first part of The War of the Secret Agents is dedicated to him, at least by epigraph.

HC: When Phil first arrived in the Workshop, I think we thought he was going to be a novelist. I don't know whether we read any fiction by him or not. I think we must have read at least one story, but the first poem of his that I remember is a poem about a Jewish delicatessen, and it was obviously in Detroit, and it had a certain kind of tough-guy quality. You would hardly know how good he was going to be. He used to do an odd thing. One of the important people there at the time was Donald Petersen; he and Justice were the two kings of Iowa City. And Petersen had a sort of Dr. Johnson manner about him. 
MSH: He was 6'5" and two hundred and sixty-five lbs.

HC: Yes, right, he was really impressive. He really looked like he had a fantastic fastball. Gee, I learned a lot from him. Phil used to sit at his feet and amuse Petersen by talking in rhyme. It was a crazy thing, almost a kind of psychotic gift or curse. It used to break Petersen up. But again that was part of not figuring out exactly what Phil was going to be like. That was ' 53 or ' 54 , and by the time I came back to Iowa City, in '55-'56, Phil had gone off, had gotten married, and had taken a job in Florida. They went off there for a year, and I went to Riverside. Then we both came back. That's when we really became friends, and he was really beginning to write well, and I thought I was too. We were sort of going down the road together, doing very similar things, influencing each other, supporting each other in what we were doing. He wrote a series of Algerian war poems at the same time that I was working on "The War of the Secret Agents."

I owe "Moby Jane" to Phil. One night we were getting drunk and being funny, or at least we thought we were. I forget what the sequence of play was, but at some point or other, in fooling around verbally, he said something like, "Moby Jane," and I thought, oh my god, I wish I had thought of that. And as we kept on talking, I made up a fighter named Baby Villon, and he said, "I want that, I want Baby Villon." I said he could have it, if I could have Moby Jane. So we traded.

MSH: In the beginning of "The Junk Shop" section, in The War of the Secret Agents there are four lines from Levine:

The surprise was that there was nothing there, Nothing at all, nothing, not even ought, And thus it was that in my 35 th year I learned that by these words I hid my thought.

HC: Those four lines summed up very well where I thought I was, myself, at roughly that age. I wanted to get something of Phil's in there, because we were so close. These four lines come out of "The Receiver," and the complete three sections of it, as I once told you, are there because I preserved parts two and three when he had lost them. I thought that was a marvelous, mad, wacky poem. I like Levine best when the technique, craziness, and subject matter come together.

MSH: Where did he learn the technique?

HC: He learned it at Iowa from being in a class with people like Justice 
and Snodgrass, and he also learned it from Yvor Winters, although he likes to cover up the Winters debt.

Phil and I both owe a hell of a lot to Snodgrass, technically. Dee knew how to write in form, sometimes almost a little awkwardly. I always had the feeling that his ability to read covered up the fact that sometimes there were awkward moments in the poem. But I mean, god, really, the whole impact of his ability to do the fifties kind of thing, (not just the fifties, all of that started back in the thirties, and went on through) of wanting to go back and get the forms, polish it, make it neato, and also say something. That was it! He also had something to say. That was the great innovation.

Now when you compare him to Justice, in The Summer Anniversaries, ah, let's say that from my point of view, Heart's Needle and Summer Anniversaries, both published in ' 59 , stand up almost like Harmonium and White Buildings, as among the great first books of our century. Don had an extraordinary ear. He has the best ear of any poet I know of. Except it's sometimes a little weak in syllabics, I think, but anyway, an extraordinary ear, and those poems, I mean, goddamn, those things were fantastic. One of the most difficult things to work in is accentuals. Justice had written the "Patient B" poem, which is the most fantastic demonstration of accentuals that I know of, a five beat line, which is almost impossible to do. I got interested in trying to do accentuals; that's where that came from in my work. We knew that Justice was doing it; we could see that. Dee could not write as well as Don by a long shot, in terms of just technique. But in terms of being innovative, of seeing possibilities, of breaking out of the historical closet, and saying " $\mathrm{Hi}$ there, this is Snodgrass, walking through the universe," you know. That was it. And that made it possible for Levine, I think to write his "I'm standing here at the intersection of Barcelona and Detroit in beautiful downtown Fresno," and to realize that it can be important that you're feeling something when you get up in the morning and your wife is still asleep or she's out in the garden, or whatever. Because it's always hard to bring art and life together and to feel that you're worthy of talking about your experience.

MSH: Well, where do you fit into all of this, I mean in your estimation as you look back. There's Justice and Snodgrass, two incredibly gifted guys, and Berryman coming in who is obviously insane, extremely bright, very able to get people focused. I mean the mere fact of pulling down a thirty person group to thirteen and having that kind of produc- 
tivity out of those particular people, the ability to give a certain kind of direction to all kinds of things. And then Lowell. Where do you fit in?

HC: Well, we could expand the frame of reference. Someone once pointed out to me how many poets were born about when I was, in the mid-twenties. The list is legion, not only Justice, Snodgrass and Levine, of whom I've been talking, but Hecht, Dickey, Dugan, Simpson, Levertov, Schuyler, Koch, Ammons, Merrill, Creeley, Ginsberg, O'Hara, Blackburn, Bly, Ashberry, Merwin, Wright, Feldman, Sexton, and Hall. That's just by checking the table of contents of one large anthology, the years '23 through '28. I'm part of that explosion and, like several others on that list, came about in part by the G.I. Bill. We had people in the Workshop from the universities of the privileged, the Ivy League, but we also had the veterans and people from places like Wayne State and Miami. The have-nots were at the gates, worksheets in hand.

MSH: And you, Hank?

HC: Answering questions like yours is like shaving without a mirror. I believe this though, if we're ignorant of history, we're condemned to repeat its evils. If we know history, we're obligated to repeat its virtues, its beauties.

I feel much more comfortable with my subject matter, which in some sense is really human experience. I've had fifty-odd years of that. Once, I don't know if I ever told you this or not, once I took a course in Existentialism because I was looking for something to say. But that's way back then. More and more I am interested in history. Some popular novelist, maybe a mystery writer, said that the reason he really wrote books was because there weren't enough of the kind he liked to read. Really that's why I've gone back to writing poems; there aren't enough of the kind I like. I'm obligated. I make the lobby and the street look real. 